\title{
UPAYA MENINGKATKAN HASIL BELAJAR MATEMATIKA MATERI SISTEM PERSAMAAN LINIER DUA VARIABEL MELALUI MODEL COOPERATIVE LEARNING TIPE STUDENT TEAM ACHIEVEMENT DIVISION (STAD) PADA SISWA KELAS VIII A SMP NEGERI I CUGENANG
}

\author{
Cahya Sunarya \\ SMP Negeri I Cugenang \\ sunaryacahya@gmail.com
}

Diterima: 30 Desember 2018

\begin{abstract}
ABSTRAK
Penelitian Tindakan Kelas ini bertujuan untuk memperbaiki kinerja guru dan meningkatkan hasil belajar Matematika pada siswa kelas VIII A SMP Negeri I Cugenang. Penelitian ini merupakan penelitian kualitatif, subjek penelitian adalah guru mata pelajaran matematika SMP Negeri I Cugenang, data diperoleh melalui observasi, wawancara dan dokumen. Analisis data melalui mereduksi data, menyajikan data, dan menarik kesimpulan. Keabsahan data dilakukan dengan memperpanjang waktu penelitian. Triangulasi data, dan member cheking. Data dianalisis dengan model interaktif. Hasil penelitian menunjukan bahwa (a) supervisi akademik meliputi perencanaan pembelajaran; (b) prinsip-prinsip supervisi akademik meliputi; praktis, objektif, kooperatif dan komprehensif. Model pembelajaran yang digunakan yaitu Cooperative Learning tipe STAD. Model Cooperative Learning muncul dari konsep bahwa siswa akan lebih mudah menemukan dan memahami konsep yang sulit jika mereka saling berdiskusi dengan temanya. Siswa secara rutin bekerja dalam kelompok untuk saling membantu memecahkan masalah yang kompleks. Tipe STAD ini merupakan salah satu tipe dari model Cooperative Learning dengan mengunakan kelompok-kelompok kecil dengan jumlah anggota tiap kelompok 4-5 orang siswa secara heterogen.
\end{abstract}

Kata Kunci: Hasil Belajar, Matematika, Model Cooperative Learning Tipe Student Team Achievement Division (STAD)

\section{PENDAHULUAN}

Pembelajaran berbasis kompetensi menekankan pada pencintaan dan peningkatan serangkian kemampuan, dan potensi siswa agar dapat mengantisipasi tantangan kehidupan masa depan. Kalau dulu pembelajaran itu lebih ditekankan pada aspek pengetahuan dan materi yang cenderung verbalistik dan kurang memiliki daya terap, saat ini lebih ditekankan pada aspek kompetensi dan keterampilan. Dengan pembelajaran berbasis kompetensi ini diharapkan lebih bermutu dan kualiatas lulusan lebih bermakna dalam kehidupan. Agar kemampuan berfikir matematis tingkat tinggi berkembang, maka pembelajaran harus menjadi lingkungan dimana siswa dapat terlibat secara aktif dalam banyak hal kegiatan matematis yang bermanfaat pada pelaksanaan pembelajaran. 
Belajar matematika berfungsi mengembangkan kemampuan menghitung, mengukur, menurunkan, dan menggunakan rumus matematika yang diperlukan dalam kehidupan sehari-hari melalui materi aljabar, geometri, logika matematika, peluang dan statistika.

Matematika sangat penting dalam kehidupan sehari-hari itu, matematika juga mempunyai ciri khas sebagai ilmu yang memiliki obyek astrak, berpola pada pemikiran deduktif akasiomatik, dan juga berlandaskan pad kebenaran. Dengan adanya ciri khas tersebut, matematika berguna sekali dalam menumbuh kembangkan kemampuan serta membentuk pribadi siswa dalam ilmu pengetahuan teknologi (IPTEK). Matematika sebagai ilmu dasar juga diperlukan untuk mencapai keberhasilan yang berkualitas tinggi. Oleh karena itu, sudah seharusnya matematika diajarkan sedini mungkin. Dalam hal ini, guru mempunyai peranan penting dalam mencapai keberhasialan proses belajar, termasuk keberhasilan dalam pendidikan secara global. Keberhasilan tersebut dapat ditunjukkan dengan kemampuan siswa memahami dan mengerti materi yang diajarkan.

Pada hakikatnya, matematika sebagai salah satu ilmu eksak mengharuskan para siswa untuk benar-benar mengerti dan mengusai materi. Karena alasan inilah, sebagian besar siswa mengambil kesimpulan bahwa matematika merupakan mata pelajaran yang sulit, sukar dipahami, dan tidak sedikit siswa kelas VIII A SMP Negeri I Cugenang yang menjadikan matematika merupakan pelajaran yang dianggap paling sulit, jika dibandingkan dengan mata pelajaran yang lain. Hal ini diketahui dari nilai yang diperoleh siswa masih belum memuaskan. Menurut mereka, terdapat beberapa alasan yang menyebabkan nilai mata pelajaran matematika masih belum memuaskan. Diantaranya adalah menyampaikan metode, penyampaian materi yang kurang menarik, pengelolaan kelas yang kurang mendukung, kurangnya konsentrasi siswa dalam menerima pelajaran, serta faktor kurangnya latihan. Akibatnya siswa mendapatkan nilai yang belum memuaskan, sebagian siswa berpendapat bawa matematika hanyalah mata pelajaran biasa. Oleh karena itu, peneliti mencoba memberi model pembelajaran yang menarik, materi Sistem persamaan Linear Dua Variabel karena materi tersebut ada dikelas VIII.

Berdasarkan permasalahan tersebut, tindakan yang akan dilakukan ditunjukkan untuk mengubah pandangan siswa yang berpendapat bahwa matematika merupakan pelajaran yang sulit. Munculnya pandangan tersebut menjadi salah satu penyebab terganggunya proses belajar mengajar mata pelajaran matematika. Akibatnya para siswa kesulitan dalam menyerap materi yang disampaikan, salah satunya dalam menyelasaikan soal-soal Sistem persamaan Liniear Dua Variabel. 
Untuk mengetahui apakah siswa telah berhasil mengusai materi yang disampaikan oleh guru, peneliti akan menerapkan Cooperative Learning tipe STAD. Cooperative Learning muncul dari konsep bahwa siswa akan lebih mudah menemukan dan memahami konsep yang sulit jika mereka saling berdiskusi dengan temanya. Siswa secara rutin bekerja dalam kelompok untuk saling membantu memecahkan masalah yang kompleks. Tipe STAD ini merupakan salah satu tipe dari model Cooperative Learning dengan mengunakan kelompok-kelompok kecil dengan jumlah anggota tiap kelompok 4-5 orang siswa secara hiterogen. dengan menerapkan Tipe $S T A D$ diharapkan secara individu akan membangun kepercayaan diri terhadap kemampuannya dalam menyelesaikan masalahmasalah matematika, sehingga secara berangsur-angsur akan mengurangi rasa cemasnya terhadap kesulitan yang sebelumnya dialami. Cooperative Learning juga terbukti sangat bermanfaat bagi para siswa yang hiterogin. Dengan menonjolkan interaksi dalam kelompok, model belajar ini dapat membuat siswa mampu menerima siswa lain yang berkemampuan berbeda. Adanya kompetensi antar kelompok siswa belajar juga dapat menumbuhkan motivasi belajar para siswa yang nantinya akan berpengaruh terhadap hasil belajar. Dari urian diatas, maka peneliti tertarik untuk melakukan penelitian tindakan kelas dengan judul "Meningkatkan Hasil Belajar Matematika Materi Sistem Persamaan Linier Dua Variabel melalui Model Cooperative Learning Tipe Student Team Achievement Division (STAD ) di Kelas VIII A SMP Negeri I Cugenang Tahun Pelajaran 2015/2016”.

\section{Cooperative Learning}

Pendekatan pembelajaran merupakan jalan yang akan ditempuh oleh guru dan siswa dalam mencapai tujuan instruksional untuk suatu satuan instruksional tertentu. Pendekatan pembelajaran merupakan aktivitas guru dalam memilih kegiatan pembelajaran. Pada pokoknya pendekatan pembelajaran dilakukan oleh guru untuk menjelaskan meteri pelajaran dari bagian yang satu dengan bagian lainnya berorientasi pada pengalamanpengalaman yang dimiliki siswa.

Sistem pendekatan pembelajaran dibuat karena adanya kebutuhan akan sistem dan pendekatan tersebut untuk meyakinkan: a) ada alasan untuk belajar dan b) siswa belum mengerti apa yang akan diajarkan. Dari penjabaran di atas dapat disimpulkan bahwa pembelajaran adalah suatu proses penyampaian berbagai macam konsep, informasi dan aktifitas kepada siswa yang dilakukan oleh guru dengan tujuan untuk membantu siswa supaya dapat belajar dengan mudah serta tercapainya tujuan belajar mengajar. 
Hasil belajar menggambarkan kemampuan siswa dalam mempelajari sesuatu. "Hasil belajar adalah kemampuan yang dimiliki atau dikuasai siswa setelah menempuh proses belajar". Hasil belajar mencakup kemampuan kognitif (intelektual) afektif (sikap), dan kemampuan psikomotorik (bertindak). Harus diakui bahwa dalam proses belajar mengajar, terutama yang berkenaan dengan perubahan konsep sistem persamanan linear dua variabel, sedikit sekali kemapuan yang berkenaan dengan sikap, yang lebih banyak adalah aspek kognitif dan psikomotorik.

Istilah matematika berasal dari kata yunani "mathein", yang artinya mempelajari. Matematika sering kali dikatakan ilmu pasti, kata ilmu pasti merupakan terjemahan dari bahasa belanda "wiskunde". Penggunaan kata "ilmu pasti atau wikunde" untuk "mathematics" seolah-olah membenarkan pendapat bahwa di dalam matematika semua hal sudah pasti dan tidak bisa diubah lagi. Padahal, kenyataan sebenarnya tidaklah demikian. Dalam matematika, banyak terdapat pokok bahasan yang justru tidak pasti, misalnya dalam statistika dan probabilitas(kemungkinan), perkembangan dari logika konvensional yang memiliki 0 dan 1 ke logika fuzzy yang bernilai antara 0 sampai 1, dan seterusnya. Dengan demikian belajar matematika sama halnya dengan belajar logika, karena kedudukan matematika dalam ilmu pengetahuan adalah sebagai ilmu dasar atau ilmu alat. Untuk dapat berkecimpung di dunia sains, teknologi,atau disiplin ilmu lainnya, yang harus ditempuh ilmu dasarnya yaitu menguasai matematika secara benar.

Berbagai pendapat muncul tentang pengertian matematika, dipandang dari pengetahuan dan pengalaman masing-masing yang berbeda. Berdasarkan etimologis, perkataan matematika berarti "Ilmu pengetahuan yang diperoleh dengan bernalar". Hal ini dimaksudkan bukan berarti ilmu pengetahuan lain diperoleh tidak melalui penalaran, akan tetapi dalam matematika lebih menekankan aktifitas dalam dunia rasio (penalaran), sedangkan dalam ilmu lain lebih menekankan hasil observasi atau eksperimen di samping penalaran. Johnson dan Rising (1972) dalam bukunya mengatakan bahwa matematika adalah pola berpikir, pola mengorganisasikan, pembuktian yang logik, matematika itu adalah bahasa yang menggunakan istilah yang didefinisikan dengan cemat, jelas, dan akurat, representasinya dengan simbol dan padat, lebih berupa bahasa simbol mengenai ide daripada amengenai bunyi.

Cooperative Learning merupakan strategi belajar yang menempatkan siswa belajar dalam kelompok yang beranggotakan 4-5 siswa dengan tingkat kemampuan atau jenis kelamin atau latar belakang yang berbeda. Pembelajaran ini menekankan kerja sama dalam kelompok untuk mencapai tujuan yang sama. Selain itu sebelum Cooperative Learning 
yang akan digunakan dalam kelompok belajar. Keterampilan Cooperative Learningitu antara lain menghargai pendapat orang lain, mendorong partisipasi, berani bertanya, mendorong teman untuk bertanya, mengambil giliran dan berbagai tugas dan sebagainya.

Cooperative berarti bekerjasama dan Learning berarti belajar, jadi belajar melalui kegiatan bersama. Namun tidak semua belajar bersama adalah Cooperative Learning, dalam hal ini belajar bersama melalui teknik-teknik tertentu. Cooperative Learning (pembelajaran kooperatif) merupakan suatu model pembelajaran dengan menggunakan kelompok kecil, bekerja sama. Keberhasilan dari model ini sangat tergantung pada kemampuan aktivitas anggota kelompok, baik secara individual maupun dalam bentuk kelompok.

Cooperative Learning mencakup suatu kelompok kecil siswa yang bekerja sebagai sebuah tim untuk menyelesaikan sebuah masalah, menyelesaikan suatu tugas, atau mengerjakan sesuatu untuk mencapai tujuan bersama lainnya. Tidaklah cukup menunujukkan sebuah cooperative learning jika para siswa duduk bersama didalam kelompok-kelompok kecil tetapi menyelesaikan masalah secara sendiri-sendiri. Cooperative Learning menekankan pada kehadiran teman sebaya yang berinteraksi antar sesamanya sebagai sebuah tim dalam mnyelesaikan atau membahas suatu masalah.

Menurut Slavin (2010),“Cooperative Learning adalah suatu model pembelajaran dimana siswa belajar dan bekerja dalam kelompok kecil secara kolaboratif yang anggotanya 4-6 orang, dengan struktur kelompok heterogen“. Sedangkan Djahiri K (1983) menyebutkan Cooperative Learning sebagai pembelajaran kelompok Cooperative yang menuntut diterapkannya pendekatan belajar yang siswa sentris, humanistik dan demokratis yang disesuaikan dengan kemampuan siswa dan lingkungan belajarnya. Cooperative Learning lebih dari sekedar belajar kelompok atau kelompok kerja, karena belajar dalam model Cooperative Learning harus ada "Struktur dorongan dan tugas yang bersifat Cooperative Learning" sehingga memungkinkan terjadinya interaksi secara terbuka dan hubungan-hubungan yang efektif diantara anggota kelompok. Abdurrahman dan Bintoro memberi batasan model Cooperative Learning sebagai pembelajaran yang secara sadar dan sitematik mengembangkan interaksi yang silih asah, silih asih dan silih asuh antar sesama siswa sebagai latihan hidup dalam masyarakat nyata.

Cooperative Learning merujuk pada berbagai macam metode pengajaran dimana para siswa bekerja dalam kelompok-kelompok kecil untuk saling membantu satu sama lainnya dalam mempelajari materi pelajaran. Dalam kelas Cooperative Learning para siswa diharapkan dapat saling membantu, saling mendiskusikan, dan berargumentasi 
untuk mengasah pengetahuan yang mereka kuasai saat itu dan menutup kesenjangan dalam pemahaman masing-masing. Cooperative Learning merupakan model pembelajaran yang mengutamakan kerjasama diantara siwa untuk mencapai tujuan pembelajaran. Cooperative Learning dapat menciptakan saling ketergantungan antar siswa, sehingga sumber belajar bagi siswa bukan hanya guru dan buku ajar tetapi juga sesama siswa.

Cooperative Learning merupakan model pembelajaran yang diupayakan untuk dapat meningkatkan peran serta siswa, memfasilitasi siswa dengan pengalaman sikap kepemimpinan dan membuat keputusan dalam kelompok, serta memberikan kesempatan kepada para siswa untuk berinteraksi dan belajar secara bersama meskipun mereka berasal dari berbagai latar belakang yang berbeda. Menurut Kindvatter dkk (1996), yang menjadi fokus dari belajar bersama adalah kemajuan bidang akademik dan afektif melalui kerjasama.

\section{METODOLOGI PENELITIAN}

Penelitian ini menggunakan jenis penelitian tindakan kelas. Subjek penelitiannya yaitu siswa kelas VIII A SMP Negeri I Cugenang Cianjur. Materi yang digunakan yaitu Sistem Persamaan Linier Dua Variabel (SPLDV). Pada penelitian ini menggunakan instrumen tes ( tes siklus) dan non tes (lembar observasi).

\section{HASIL DAN PEMBAHASAN}

Berdasarkan hasil perolehan nilai peserta didik kelas VIII A sebelum dan sesudah pembelajaran matematika dengan menggunakan model Cooperative Learning tipe STAD pada materi Sistem Persamaan Linier Dua Variabel (SPLDV) di kelas VIII A SMP Negeri I Cugenang Cianjur yang dilaksanakan 2 siklus. Setiap siklus terbagi menjadi 3 tahap, yaitu: 1) tahap awal, 2) tahap inti, dan 3) tahap akhir. Tahap awal meliputi : 1) Guru membagi 38 siswa kelas VIII A dalam 9 kelompok belajar. Cooperative Learning tipe STAD (kelompok ), yang masing-masing kelompok terdiri dari 4 dan 5 orang siswa. 2) guru menjelaskan materi secara garis besarnya saja (klasikal), dan 3) guru memberi soal kuis materi pelajaran pada kelompok, sedangkan dalam kelompok terdiri dari 1 siswa berkamampuan tinggi, 3 siswa berkemampuan sedang, dan 1 siswa berkemampuan rendah.

Tahap inti meliputi: 1) Guru menyuruh siswa untuk membentuk kelompok yang sudah guru tetapkanuntuk menduskusikan soal kuis urian dengan waktu yang sudah ditentukan, 2) Guru menugaskan siswa untuk setiap kelompok dan mempresentasikan topik bagian dalam kelompok secara bergiliran sesuai waktu yang ditentukan, dan 3) Guru 
memberikan penghargaan kepada masing-masing kelompok asal. Tahap akhir, yaitu: pemberian soal tes evaluasi (post tes) secara individu pada setiap akhir siklus. Tes tersebut dilakukan untuk mengetahui prestasi dan ketuntasan belajar siswa setelah diterapkan Cooperative Learning tipe STAD.

Pada pelaksanaan siklus I dan siklus II tahap-tahap tersebut telah dilaksanakan dan telah memberikan perbaikan yang positif dalam diri siswa. Hal tersebut dibuktikan dengan keaktifan siswa dalam mengikuti pembelajaran matematika di kelas, misalnya siswa yang semula pasif dalam belajar kelompok sudah menjadi aktif dan siswa dalam menyelesaikan soal tes tidak ada lagi yang contekan dengan temannya karena siswa sudah yakin dengan kemampuannya sendiri.

Berdasarkan hasil penelitian ini, bahwa peserta didik secara umum memperoleh hasil yang baik pada materi Sistem Persamaan Linier Dua Variabel. Selain itu, berdasarkan hasil pengamatan terhadap masalah-masalah selama pelaksanaan proses pembelajaran pada siklus I dari hasil tes akhir, dan catatan lapangan diperoleh hasil sebagai berikut:

1. Prestasi belajar siswa berdasarkan hasil tes siklus I menunjukkan bahwa prestasi belajar siswa belum bisa memenuhi ketuntasan belajar yang diharapkan

2. Siswa kurang aktif menyampaikan pendapat dalam diskusi kelompok

3. Dalam menyelesaikan soal kuis maupun tes evaluasi masih ada siswa yang contekan dengan temannya.

Masalah-masalah di atas timbul disebabkan oleh faktor-faktor antara lain:

1. Siswa belum terbiasa dengan pelaksanaan Cooperative Learning tipe STAD yang diberikan peneliti

2. Siswa belum terbiasa belajar kelompok yang anggotanya dibentuk secara heterogen

Pada siklus I belum menunjukkan adanya peningkatan partisipasi aktif dari siswa, belum adanya peningkatan hasil belajar siswa karena ketuntasan belajar siswa masih belum memenuhi keinginan yang diharapkan, serta belum adanya keberhasilan dalam melaksanakan Cooperative Learning tipe STAD. Oleh kareana itu perlu dilanjutkan pada siklus II agar prestasi belajar matematika siswa bisa ditingkatkan sesuaia dengan harapan.

Selanjutnya setelah merefleksi hasil sikus I, peneliti mengkonsultasikan dengan guru bidang studi matematika kelas VIII A untuk melanjutkan ke siklus II. Setelah memperoleh persetujuan peneliti langsung menyusun rencana pelaksanaan siklus II. 
Berdasarkan hasil observasi, hasil catatan lapangan, hasil wawancara, hasil tes akhir dapat diperoleh beberapa hal sebagai berikut:

1. Aktivitas guru/peneliti sudah menunjukkan tingkat keberhasilan pada kriteria sangat baik. Oleh karena itu tidak diperlukan pengulangan siklus.

2. Aktivitas siswa sudah menunjukkan tingkat keberhasilan pada kriteria sangat baik. Oleh karena itu tidak diperlukan pengulangan siklus

3. Kepercayaan diri pada siswa sudah meningkat dibuktikan dengan pengendalian pada teman/orang lain berkurang, sehingga tidak ada lagi siswa yang contekan dalam menyelesaikan soal-soal evaluasi maupun kuis. Oleh karena itu tidak diperlukan pengulangan siklus

4. Kegiatan pembelajaran menunjukkan penggunaan waktu yang sudah sesuai dengan rencana. Oleh karena itu tidak diperlukan pengulangan siklus

5. Prestasi belajar siswa berdasarkan hasil tes akhir II menunjukkan bahwa prestasi belajar siswa terhadap materi sudah baik, hal tersebut dibuktikan dengan ketuntasan belajar siswa telah memenuhi KKM yang diinginkan. Oleh karena itu tidak diperlukan pengulangan siklus.

Hasil observasi pada siklus I pengamatan aktivitas peneliti 79,28 \% , aktivitas siswa 77,5 \% masuk dalam kategori baik, pada siklus II pengamatan aktivitas peneliti $90 \%$, aktivitas siswa $88 \%$ masuk dalam kategori sangat baik. Begitu juga dengan hasil evaluasi untuk siklus I yaitu 83.94, untuk siklus II yaitu 85, Dari hasil evaluasi tersebut dapat diketahui bahwa ada peningkatan yang signifikan pada rata-rata hasil belajar siswa dari Siklus I ke siklus II, yaitu sebesar 1.05. Hal ini menunjukkan bahwa pada siklus I ketuntasan belajar siswa belum tercapai yaitu sebesar 83.94, sedangkan pada siklus II meningkat menjadi 85 yang suadah memenuhi kriteria ketuntasan minimum (KKM) 75 dan ketuntasan belajar siswa 85, pada siklus II menunjukkan peningkatan sebesar 1.05. Dengan demikian pada siklus II telah mencapai target, bahwa Coopetive Learning tipe STAD mampu meningkatkan hasil prestasi belajar matematika.

Dari uraian pengamatan di atas pada siklus II, secara umum pada siklus II sudah menunjukkan adanya peningkatan partisipasi aktif dari siswa dan adanya peningkatan prestasi belajar bagi siswa serta keberhasilan guru/peneliti dalam menggunakan pendekatan Cooperative Learning tipe STAD. Oleh karena itu tidak perlu dilanjutkan pada siklus berikutnya dan tahap penelitian berikutnya adalah penulisan laporan. 


\section{KESIMPULAN}

Berdasarkan hasil penelitian dan pembahasan maka dapat disimpulkan bahwa penerapan Model Cooperative Learning tipe STAD dapat meningkatkan hasil prestasi belajar siswa pada pokok bahasan Sistem Persamaan Linier Dua Variabel (SPLDV), Hasil observasi aktivitas peneliti dan aktivitas siswa mengalami peningkatan dari kategori baik ke sangat baik.

\section{DAFTAR PUSTAKA}

Johnson dan Rising. 1972. Guidelines for Teaching Mathematics. California: Wadsworth Publising Company, Inc

Kindsvatter, R., W. Wile, and M. Ishler. (1996). Dynamic of Effective Teaching. London: Longman Publisher.

Kosasih, Djahiri A. (1983). Pengajaran Studi Sosial IPS. Bandung: LPPP IPS IKIP.

Robert. E Slavin. (2010). Cooperative Learning Teori, Riset dan Praktik. Bandung:Nusa Media. 